\title{
Sarcomere Structure: The Importance of Desmin Protein in Muscle Atrophy
}

\author{
Estructura de Sarcómera: La Importancia de Proteína Desmina en Atrofia Muscular
}

\author{
Gabriel Nasri Marzuca-Nassr'; Kaio Fernando Vitzel²; Eladio Mancilla-Solorza ${ }^{3}$ \& José Luis Márquez
}

MARZUCA-NASSR, G. N.; VITZEL, K. F.; MANCILLA-SOLORZA, E. \& MÁRQUEZ J. L. Sarcomere structure: The importance of desmin protein in muscle atrophy. Int. J. Morphol., 36(2):576-583, 2018.

SUMMARY: Knowing the ultrastructure of skeletal muscle is critical to understand how it works under normal situation and the disorders caused by extreme or pathological conditions. Sarcomere is the basic structural unit of striated muscle tissue. An important element of sarcomere architecture are the intermediate filaments, including the desmin protein. Desmin protein contributes to maintenance of cell integrity, efficient transmission of force and mechanochemical signaling within the myocyte. Because of this, desmin protein has constantly been a focus of research that investigates its alterations associated to damage and muscle atrophy under different conditions. The purpose of the following literature review is to describe the basic concepts of muscle ultrastructure, emphasizing the desmin protein role under conditions of muscle disuse atrophy and aging.

KEY WORDS: Sarcomere; Desmin; Muscle disuse atrophy; Hindlimb suspension; Aging; Intermediate filaments.

\section{INTRODUCTION}

The skeletal muscle cells are organized from contractile units know as sarcomeres, which are the structural subunits arranged in a repeated pattern, along the length of the cells (Sanger et al., 2010). The sarcomere holds properties that are crucial for its function: 1) fast and efficient shortening, 2) millisecond activation/inactivation, and 3) precise structural self-assembly. These properties are intimately dependent on the structure and interaction of their constituent proteins, which can be grouped into three functional categories: contractile, regulatory and structural (Craig \& Padrón, 2004).

The contractile proteins actin and myosin, together with the structural proteins (e.g., titin and nebulin) and intermediate filaments, create a solid and efficient muscular architecture. Desmin is the largest intermediate filament, and its impaired expression can cause major alterations on myofibrillar function (Ansved \& Edstrom, 1991; Chopard et al., 2001; Cízková et al., 2009; Hnia et al., 2011). The present literature review describes the main components of muscular ultrastructure, emphasizing the relevance of desmin on disuse-induced atrophy and aging-related muscle loss.

\section{SARCOMERE STRUCTURE}

The sarcomere is the skeletal muscle functional unit arranged between two Z-lines (Fig. 1) (Hopkins, 2006). In vertebrate skeletal muscle, its rest length is $\sim 2.5 \mathrm{~mm}$. The Z-lines are the anchoring site of $\alpha$-actinin, titin and several intermediate filaments, including desmin and vimentin. During skeletal muscle growth/development, the first myofibrils are observed next to the cell membrane, indicating that the early sarcomere assembly occurs at the inner cell periphery (Sparrow \& Schöck, 2009). Despite the extensive investigations about myofibril assembly, the molecular mechanisms that control sarcomere construction, structural organization and how it reflects on the sarcomere function remain unclear (Grosberg et al., 2011).

The Z-line proteins create a special network of interactions that acts as a scaffold and connects the thin filaments from adjacent sarcomeres (Sanger et al.). Titin and $\alpha$-actinin $(190 \mathrm{kDa})$ are ubiquitously expressed structural proteins of the Z-line. The latter is composed of antiparallel homodimers that crosslink the thin actin filaments of neighboring sarcomeres (Yu et al., 2003). The two sarcomeric a-actinin isoforms ( $\alpha$-actinin-2 and -3 ) are major

\footnotetext{
${ }^{1}$ Department of Internal Medicine, Faculty of Medicine, Universidad de La Frontera, Temuco, Chile.

${ }^{2}$ School of Health Sciences, College of Health, Massey University, Auckland, New Zealand.

${ }^{3}$ Department of Kinesiology, Faculty of Health Sciences, Universidad Católica del Maule, Talca, Chile.

${ }^{4}$ School of Kinesiology, Faculty of Medical Sciences, Universidad de Santiago de Chile, Santiago, Chile.
} 


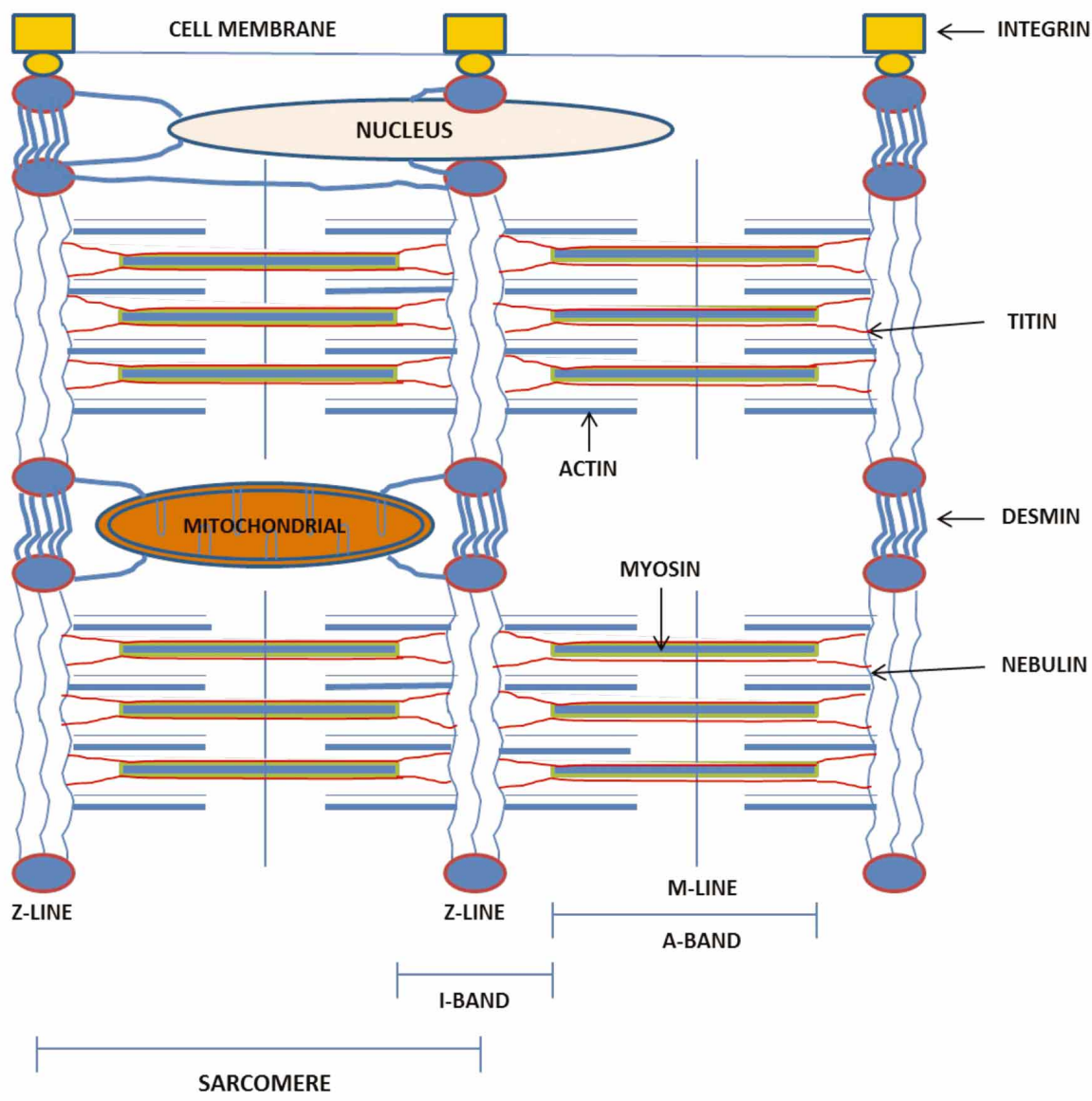

Fig. 1. Sarcomere structure. Thin filaments (actin) are linked by $\alpha$ actinin and anchored on both sides of the Z-line forming the limits of the sarcomere. Thin filaments also contain nebulin, a regulator of the length of this polymer in vertebrates. The thick filaments (myosin) are anchored to the M-line that divides the sarcomere in half. The area where the thick filaments are located is known as A-band. The area on both sides of the Z-line where the thin filaments are not overlapping the thick filaments is known as I-band. Titin protein extends from the $\mathrm{M}$ - to $\mathrm{Z}$-line. Intermediate filaments, particularly desmin, surrounds the sarcomeres in the Z-line and creates a connection with others sarcomeres and the cell membrane. Desmin provides the maintenance of cell integrity, efficient transmission of force and mechanochemical signaling within the cell.

components of the Z-line. A study that investigated skeletal muscle contractile properties of $\alpha$-actinin- 3 knockout mice showed a reduction of muscle force production and increased susceptibility to eccentric contraction-induced damage, indicating that this protein is essential for powerful repetitive muscle contractions (Seto et al., 2011).

The M-line, which is located at the A-band center and splits the sarcomere in half, comprises another set of structural proteins. It interacts directly with the tail domain of myosin filaments and indirectly with the thin filaments (through connecting proteins - mainly nebulin) (Hopkins; Rui et al., 2010). It was suggested that the M-line could reduce the intrinsic instability of the thick filaments and assist titin on the maintenance of the sarcomere structure. The molecular organization of the M-line indicates that myomesin is one of its key components, forming antiparallel dimers that connect the thick filaments to the $\mathrm{M}$-line, a role analogue to $\alpha$-actinin in the Z-line (Agarkova \& Perriard, 2005).

Thick Filaments. The thick filaments ( $16 \mathrm{~nm}$ of diameter) are bipolar polymers and the protein myosin is its major component. The myosin binding protein (MyBP) and the elastic protein titin are also elements of the thick filaments (Gordon et al., 2000).
Myosin. Myosin II protein (the isoform present in skeletal muscle) consists of a globular head and a tail (Hopkins). It is composed of two heavy chains with a molecular weight of $\sim 200 \mathrm{kDa}$ each and four light chains ( $20 \mathrm{kDa}$ each), two of them named as essential and the other two named as regulatory (Gordon et al.). Myosin II presents two fragments; light meromyosin (LMM), which corresponds to two thirds of the tail and is responsible for the self-assembly of protein dimers, and heavy meromyosin (HMM), that is divided in two subfragments; the subfragment 1 (S1), which includes the motor domain, is consisted of globular heads, and the subfragment 2 (S2), which corresponds to the proximal third of the tail and acts as flexible connection between $\mathrm{S} 1$ and LMM (Craig \& Woodhead, 2006).

Myosin II is an adenosine triphosphate (ATP)dependent protein that generates force and movement along the actin filaments. The "swinging lever-arm" hypothesis of muscle contraction purposes that nucleotide-dependent small movements of the ATPase catalytic site are amplified by the rotation of the myosin molecule "neck", and it is accepted as the general mechanism by which the sarcomere shortening occurs (Shiroguchi et al., 2011). Besides myosin, the thick filaments are composed by other proteins associated to it, which, in vertebrates, are the MyBP-C (-X) of 140 
$\mathrm{kDa}$ and the MyBP-H of $86 \mathrm{kDa}$, that bind to 11 myosin sites at a regular distance of $43 \mathrm{~nm}$ (Craig \& Woodhead).

Titin. Titin ( 3 MDa), also known as connectin, is a major provider of support to the thick filaments. Each titin molecule expands along the sarcomere from the Z-line to the M-line (Hopkins; Kollár et al., 2010). Titin is considered a giant muscular protein and is the third most abundant protein in skeletal muscle (after actin and myosin). It provides the passive mechanical tension necessary for the sarcomere to restore its resting length after contraction. This role is based on titin's ability to increase its length when submitted to a longitudinal force and return to the initial length when the force ceases. Titin can act as a "molecular spring" because its $\mathrm{NH}_{2}$ and $\mathrm{COOH}$ terminals are strongly anchored to the Z-line and M-line, respectively (Kollár et al.; Tskhovrebova \& Trinick, 2010). Titin has two elastic domains composed of tandem immunoglobulin (Ig)-like modules and a unique PEVK domain (rich in the amino acid sequence of proline $(\mathrm{P})$, glutamate (E), valine (V) and lysine (K)) (Niederländer et al., 2004). The specific structural properties of the Ig-like and PEVK domains result in a distinct stiffness for each, making them work a two-spring system that act in series but are not entirely separated (Gautel \& Goulding, 1996; Niederländer $e t$ al.). This elastic system is a major contributor for the skeletal muscle passive tension development (Niederländer et $a l$.).

Thin Filaments. The thin filaments are connected to the Zline, extend perpendicularly towards the M-line and along the length of the fiber, interdigitated with the thick filaments (Hopkins). The thin filaments ( 10 nm of diameter) are composed mainly by actin, tropomyosin, the troponin complex with its three subunits, tropomodulin and nebulin (Gordon et al.).

Actin. Actin $(42 \mathrm{kDa})$ is the most abundant protein in almost all types of cells and the regulation of its architecture is essential for proper muscle function (Hopkins; Pappas et al., 2010). Actin is a globular monomeric protein (G-actin) that spontaneously polymerizes to form filamentous-actin (F-actin), the framework of the thin filament. They are organized as two long chains with a helical structure and four subdomains (Steinmetz et al., 1997; Gordon et al.; Dominguez \& Holmes, 2011). The larger ones are subdomains 3 and 4 that interact with subdomains 3 and 4 of the second actin strand. Subdomains 1 and 2 are smaller and located in the periphery of the filament, being available for interaction with myosin, especially subdomain 1 , which contains the $\mathrm{NH}_{2}$ and $\mathrm{COOH}$ terminals of actin. This atomic model of the actin filament provides further understanding on the positioning of this protein in the actin-tropomyosin complex and on its relationship with troponin (Gordon et al.). This elaborate structural network contributes to the efficient transmission of force along the length of the myofibril (McElhinny et al., 2005).

The length regulation of the thin filaments is carried out largely by the capping proteins, CapZ and tropomodulin (Tmod). CapZ corresponds to a heterodimer $(\sim 68 \mathrm{kDa})$ formed by $a$ and $b$ subunits and covers the plus ends of actin filaments, contributing to their alignment with the Z-line. Tmod, a monomer of $\sim 40 \mathrm{kDa}$, is essential to maintain the length of the thin filaments, limiting its growth in the minusend of the molecule by preventing the depolymerization and elongation of actin filaments ( $\mathrm{Au}, 2004$; McElhinny et al.).

Nebulin. Nebulin is a giant protein $(600-900 \mathrm{kDa})$ that is also part of the thin filaments. It has a highly repetitive structure, as up to $97 \%$ of the polypeptide consists in modules of 30-35 amino acids arranged in simple or super repeats (Donner et al., 2004; Pappas et al.). It is essential for a proper regulation of the length of the thin filaments involved in muscle contraction (Pappas et al.). Nebulin deficient muscle fibers develop less tension and have a greater energy cost of force production (Labeit et al., 2011). Immunoelectron microscopy reveals that a single molecule of nebulin extends along each thin filament with its $\mathrm{COOH}$ terminal anchored to the $\mathrm{Z}$-line (plus-end) and the $\mathrm{NH}_{2}$ terminal facing the minus-end of the thin filament (Ottenheijm \& Granzier).

In the peripheral region of the Z-line, nebulin interacts with desmin, suggesting that the nebulin could be involved in maintaining the lateral alignment of myofibrils, an essential property for a coordinated and efficient contractile activity (Donner et al.; Pappas et al.) .

Tropomyosin. Weighing $\sim 37 \mathrm{kDa}$, is a large molecule with $42 \mathrm{~nm}$ of length formed as a homo or heterodimer of chains and helical structure over 7 actin subunits. The stability of the spiral is generated by hydrophobic interactions provided by the amino acids of each chain. X-ray images of tropomyosin interaction with F-actin filaments, suggest an electrostatic binding (Gordon et al.; Au). The primary function of tropomyosin is the regulation of the muscle contraction by blocking the binding sites of myosin located in actin protein. It prevents the actin-myosin interaction in relaxed state (Lin et al., 2017).

Troponin complex. $\mathrm{Ca}^{2+}$ concentrations are the initial signaling to produce muscle contraction and this is detected and transduced by troponin complex in skeletal and cardiac muscle. The troponin complex is composed of three subunits: 1) troponin $\mathrm{C}(\mathrm{TnC}), 18 \mathrm{kDa}$, which has binding sites for calcium; 2) troponin I (TnI), 20-24 kDa, coupled with actin, 
which interferes with the binding of myosin to actin at low calcium concentrations (inhibitory effect); and 3) troponin T (TnT), 31-36 kDa, that binds the troponin complex with tropomyosin. One troponin complex is present for every seven actins molecules along thin filaments (Gordon et al.; Moore et al., 2016; Lin et al., 2017).

In short, for muscle contraction to be generated, the calcium released from the sarcoplasmic reticulum will bind to $\mathrm{TnC}$, inducing conformational changes that alter the inhibitory action of TnI and consequently also alter the position of tropomyosin protein on actin filaments, freeing the active sites in actin filaments for the binding of myosin heavy heads, allowing the formation of cross bridges (Yanagida \& Oosawa, 1975; Gordon et al.; Bekyarova et al., 2008; Lin et al.). Details on the regulation of cross-bridge cycling and the role of thick and thin filaments on contraction are reviewed elsewhere.

Intermediate filaments. In addition to the structures in the cytoskeleton formed by the M- and Z-line, the three-dimensional organization of thick and thin filaments is provided by an organized network of intermediate filaments which adhere to the sarcomere periphery. They are called "intermediate filaments" due to their diameter that varies between $9 \mathrm{~nm}$ (microfilaments) and $25 \mathrm{~nm}$ (microtubules) (Herrmann et al., 2009). These proteins are encoded by a family of about 70 genes (Chang et al., 2009). Intermediate filaments confer mechanical stability to the sarcomere by forming transverse connections between adjacent myofibrils, in addition to connect myofibrils to the sarcolemma and nucleus (Green et al., 2005; Craig \& Padrón).

There are a great variety of proteins that form the network of intermediate filaments. The most known are vimentin, synemin, nestin, syncoilin, skelemin, plectin and desmin.

Vimentin $(55 \mathrm{kDa})$ is a protein expressed in skeletal muscle cells and it is typical of mesenchymal tissue. Vimentin, as well as desmin (described below), has three domains: an $\alpha$ helical central zone, a head and a tail. They can form homodimers or heterodimers and are closely interrelated. During myoblast development, this protein copolymerizes with nestin and gradually disappears during subsequent differentiation to myotubes, when desmin becomes the prevailing intermediate filament (Cízková et al.).

Synemin and nestin. Both proteins are assembled with desmin and vimentin in muscle cells. Synemin protein $(\sim 230$ $\mathrm{kDa}$ ) is located at the Z-line periphery, co-polymerizing with desmin protein, and has binding sites for a-actinin and vinculin, allowing it to participate in the connection between
Z-line and cell membrane. Nestin (220-240 kDa) is coexpressed with vimentin and desmin on the Z-line during prenatal development, decreasing its expression in the postnatal period (Craig \& Padrón). The exact role of nestin has not been fully elucidated, but it probably assists on the assembly and disassembly of structural components of the cell, having a role in the morphological changes required for cell division and migration (Cízková et al.).

Syncoilin. (64 kDa) is a protein highly expressed in heart and skeletal muscle and interacts with desmin and the dystrophin-associated protein complex (DGC). DGC is a complex that connects the cytoskeleton with extracellular matrix and is important to maintain the sarcomere structure, having a principal role in force transmission (for further details see (Hughes et al., 2015). Syncoilin is expressed at the neuromuscular junction, the sarcolemma and the Z-line. In contrast to most of intermediate filaments, this protein has shown to be highly soluble and do not form filaments, therefore it was suggested that it may be involved in the organization of intermediate filaments and in the anchoring of this network to the sarcolemma through the DGC (Craig \& Padrón; Clarke et al., 2010).

Skelemin $(195 \mathrm{kDa})$ is a protein located on the M-line and is key in mediating the connection to the extracellular matrix in early stages of cell development (Deshmukh et al., 2007).

Plectin. Is a protein with a high molecular weight $(>500 \mathrm{kDa})$ linking intermediate filaments and costameres. It allows the attachment of adjacent myofibrils to the Z-line (Milner et al., 2000; Hijikata et al., 2008) and between peripheral myofibrils and the sarcolemma (Favre et al., 2011). Also, this protein anchors organelles, such as mitochondria, and the nuclei to the intermediate filament network (Winter \& Wiche, 2013).

Desmin protein is the major component of the intermediate filaments in adult muscle. In humans, this protein is encoded by a gene located on chromosome 2 q35 (DES). DES comprises nine exons within a region of $8.4 \mathrm{~kb}$ and encodes a protein of 470 amino acids. Consistent with its function, desmin is organized into three domains, a highly conserved $\alpha$-helical central region of 308 amino acids and two globular structures, the $\mathrm{NH}_{2}$ and $\mathrm{COOH}$ terminal regions, known as head and tail domains, respectively (Fig. 2) (Goldfarb \& Dalakas, 2009).

Desmin has a molecular weight of $53 \mathrm{kDa}$, exhibits a diameter of 8-14 nm (Bär et al., 2004) and is more expressed in the cardiac muscle ( $2 \%$ of total protein) when compared to skeletal muscle $(0.35 \%)$ (Goldfarb \& Dalakas). Its interaction with other intermediate filaments proteins provides a continuous network in the cytoskeleton that maintains a 

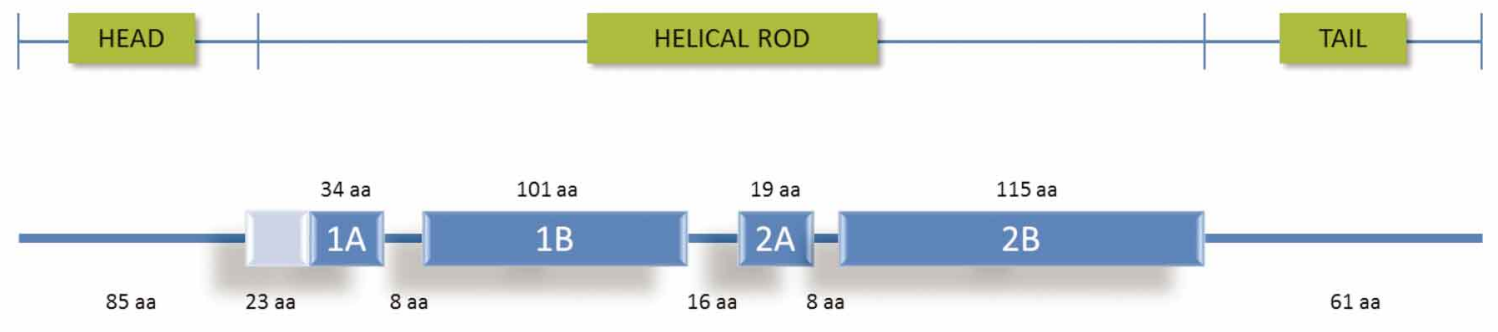

470 aa

Fig. 2. Schematic representation of desmin protein. Desmin protein is composed by 470 amino acids divided into an $\alpha$ helical central zone and two globular structures, the $\mathrm{NH}_{2}$ and $\mathrm{COOH}$ terminal regions (known as head and tail domains, respectively). The helical rod is divided in several places, resulting in four consecutive helical segments, 1A, 1B, 2A and $2 \mathrm{~B}$, connected by short non-helical links. The helical segment $2 \mathrm{~B}$ contains a discontinuity in the pattern, so most of the pathogenic mutations of desmin occur in this segment. At present there are at least 45 diseases caused by mutation of desmin gene.

spatial relationship between the contractile apparatus and other structural elements of the cell, allowing the maintenance of cell integrity, efficient transmission of force and mechanochemical signaling within the cell (Goldfarb \& Dalakas). At the same time, desmin is also linked with costameres, suggesting an influence on the organization and regulation of the extracellular matrix (Meyer \& Lieber, 2012). In striated muscle, desmin protein is located around the Z-line on the extra-myofibrillar space, forming connections around the mitochondria and in the periphery of the cell nuclei (Shah et al., 2012), which provides a mechanism where contractile activity could influence the metabolic function (Milner et al.).

Knockout mice studies have shown the importance of desmin in the early stages of myogenic development, indicating that it is essential to define the structure of skeletal and cardiac muscle. This protein is involved in the early events of myogenesis and muscle regeneration and may play a role in the proliferation of myoblasts (Carlsson \& Thornell, 2001; Smythe et al., 2001). Furthermore, it has been observed that the loss of desmin causes a disruption in the organization of muscle fibers, reduces the ability of generating force and the efficiency of force transfer across and along the fiber, leading the muscle fibers to become weaker and more susceptible to damage (Lovering et al., 2011).

Given the structural and functional characteristics of desmin, its participation in natural or induced processes involving muscular atrophy has become particularly relevant and alterations in desmin expression are being described in conditions of muscle atrophy induced by disuse and aging (Ansved \& Edstrom; Enns et al., 2007; Ogneva, 2010; Cohen et al., 2012; Marzuca-Nassr et al., 2017a).
Desmin in Muscle Disuse Atrophy: Hindlimb Suspension Animal Model. The animal model of hindlimb suspension mimics human bed rest and spaceflight conditions. In an individual special cage, the animal is maintained with the tail taped to a harness and pulley on the top of the cage. In this position, the animal moves freely using the forelimbs only, while the hind limbs cannot touch the bottom of the cage, removing the mechanical loading and causing disuse atrophy of the hindlimb muscles (Marzuca-Nassr et al., 2016; Marzuca-Nassr et al., 2017b; Marzuca-Nassr et al., 2017a).

Although an early study using an animal model of hindlimb suspension showed no changes in the relative content of desmin in the atrophic muscle (Chopard et al.), others subsequent studies have observed variations in the levels of this protein (Ogneva; Xu et al., 2012; MarzucaNassr et al., 2017a).

Ogneva conducted a study to determine the transverse stiffness of muscle fibers and content of desmin in muscles of the hind limbs: soleus, medial gastrocnemius and tibialis anterior of rats subjected to hindlimb suspension. The transverse stiffness of the sarcolemma during disuse atrophy state was reduced in all muscles (regardless of type of fiber), suggesting a direct effect of gravity as an external mechanical factor influencing sarcoplasmic membrane tension (Ogneva). The author also observed that the content of desmin in medial gastrocnemius and tibialis anterior muscles increased on days 1,3 and 7 of hindlimb suspension, but returned to baseline levels on day 12. However, the soleus muscle presented a different dynamic, wherein the content of desmin decreased by day 3 and 7 and returned to baseline levels on day 12, which implies that the contractile characteristics of the muscles 
(fiber type composition and activity pattern) determines a differential response in the content of desmin regulated by disuse (Ogneva). On the contrary, Xu et al., after two weeks of hindlimb suspension in healthy male rats $(220 \pm 10 \mathrm{~g})$, observed a decrease in the content of desmin, which was associated to the increased protein degradation in the soleus muscle. In the same line, we recently observed that the same period of hindlimb suspension also decreases the desmin protein content in soleus and extensor digitorum longus (EDL) muscles of aging rats. Conversely, the content of desmin protein significantly increases in the tibialis anterior muscle (Marzuca-Nassr et al., 2017a).

Desmin in Muscle Atrophy During Aging. Ansver \& Edstrom (1991) mention that many pathological changes seen in the muscle of old rats are similar to those induced by denervation: the presence of atrophic angular fibers, peripheral loss of myofibrillar material, sarcolemmal and nuclear membrane damage, prominent vesicles in the Golgi apparatus and proliferation and dilation of the sarcoplasmic reticulum and transverse tubules. In addition, it was observed that muscle fibers of old animals had spaces under the sarcolemma with remnants of myofilaments, including desmin (Ansved \& Edstrom).

There is controversy over changes in the levels of desmin during aging. Meyer \& Lieber, observed a decrease in the expression of desmin in the EDL, tibialis anterior, gastrocnemius and quadriceps muscles in adult subjects compared to young subject (Meyer \& Lieber). Conversely, Russ \& Grandy (2011), observed that the levels of desmin in the soleus, plantaris, medial and lateral gastrocnemius muscles are higher in adult than in old rats. Recently, Hughes et al. (2016), also comparing muscles of adult and old rats, observed that desmin protein present significantly higher levels in the tibialis anterior muscle of old rats (Hughes et al., 2016). The higher levels in desmin protein may represent a compensatory effect in aged muscle to maintain its function. Past and recent studies indicate that desmin protein plays an important role in excitation-contraction (Balogh et al., 2003; Russ \& Grandy) and force transfer (Hughes et al., 2015), processes that are impaired by aging, and higher levels in the desmin protein can help to improve the electromechanical function of the muscle fiber.

The controversies of the studies described above suggest that the effects of atrophy due to aging are different from those induced by disuse. Several investigations have been developed to understand how the different structural proteins of the skeletal muscle are affected during development or by disuse. Among these, desmin protein, the most important protein of the intermediate filaments, is of great interest, because its alteration is associated with muscle atrophy in different situations, showing differential response patterns depending on the type of muscle fibers involved. Future research should be developed in this area to understand the biological mechanisms underlying the changes in the levels of sarcomeric proteins (e.g., desmin) and how they lead to changes in the mechanochemical signaling within the muscle cell, which limit their ability to generate tension and to maintain muscle mass/integrity.

\section{FUNDING INFORMATION}

This research was carried out using financial support from Universidad de La Frontera, Proyecto DI18-0068.

MARZUCA-NASSR, G. N.; VITZEL, K. F.; MANCILLASOLORZA, E. \& MÁRQUEZ J. L. Estructura de sarcómera: La importancia de proteína desmina en atrofia muscular. Int. J. Morphol., 36(2):576-583, 2018.

RESUMEN: Conocer la ultraestructura del músculo esquelético es crítico para entender cómo trabaja bajo situaciones normales y en desórdenes causados por condiciones extremas o patológicas. La sarcómera es la unidad de estructura básica del tejido muscular estriado. Elementos importantes en la arquitectura de la sarcómera son los filamentos intermedios, incluyendo la proteína desmina. La proteína desmina contribuye en mantener la integridad celular, la transmisión eficiente de fuerza y la señalización mecanoquímica dentro del miocito. Debido a lo anterior, la proteína desmina ha sido constante foco de investigación en trabajos que estudian sus alteraciones asociadas a daño y atrofia muscular bajo diferentes condiciones. El propósito de la siguiente revisión de la literatura es describir los conceptos básicos de la ultraestructura muscular, enfatizando en el rol de la proteína desmina bajo condiciones de atrofia muscular por desuso y envejecimiento.

PALABRAS ClAVE: Sarcómera; Desmina; Atrofia muscular por desuso; Suspensión de las patas traseras; Envejecimiento; Filamentos intermedios.

\section{REFERENCES}

Agarkova, I. \& Perriard, J. C. The M-band: an elastic web that crosslinks thick filaments in the center of the sarcomere. Trends Cell Biol., 15(9):477-85, 2005.

Ansved, T. \& Edström, L. Effects of age on fibre structure, ultrastructure and expression of desmin and spectrin in fast- and slow-twitch rat muscles. J. Anat., 174:61-79, 1991.

$\mathrm{Au}, \mathrm{Y}$. The muscle ultrastructure: a structural perspective of the sarcomere. Cell Mol. Life Sci., 61(24):3016-33, 2004.

Balogh, J.; Li, Z.; Paulin, D. \& Arner, A. Lower active force generation and improved fatigue resistance in skeletal muscle from desmin deficient mice. J. Muscle Res. Cell Motil., 24(7):453-9, 2003. 
Bär, H.; Strelkov, S. V.; Sjöberg, G.; Aebi, U. \& Herrmann, H. The biology of desmin filaments: how do mutations affect their structure, assembly, and organisation? J. Struct. Biol., 148(2):137-52, 2004.

Bekyarova, T. I.; Reedy, M. C.; Baumann, B. A.; Tregear, R. T.; Ward, A.; Krzic, U.; Prince, K. M.; Perz-Edwards, R. J.; Reconditi, M.; Gore, D.; Irving, T. C. \& Reedy, M. K. Reverse actin sliding triggers strong myosin binding that moves tropomyosin. Proc. Natl. Acad. Sci. U. S. A., 105(30):10372-7, 2008.

Carlsson, L. \& Thornell, L. E. Desmin-related myopathies in mice and man. Acta Physiol. Scand., 171(3):341-8, 2001.

Chang, L.; Barlan, K.; Chou, Y. H.; Grin, B.; Lakonishok, M.; Serpinskaya, A. S.; Shumaker, D. K.; Herrmann, H.; Gelfand, V. I. \& Goldman, R. D. The dynamic properties of intermediate filaments during organelle transport. J. Cell Sci., 122(Pt. 16):2914-23, 2009.

Chopard, A.; Pons, F. \& Marini, J. F. Cytoskeletal protein contents before and after hindlimb suspension in a fast and slow rat skeletal muscle. Am. J. Physiol. Regul. Integr. Comp. Physiol., 280(2):R323-30, 2001.

Cízková, D.; Soukup, T. \& Mokr, J. Expression of nestin, desmin and vimentin in intact and regenerating muscle spindles of rat hind limb skeletal muscles. Histochem. Cell Biol., 131(2):197-206, 2009.

Clarke, W. T.; Edwards, B.; McCullagh, K. J.; Kemp, M. W.; Moorwood, C.; Sherman, D. L.; Burgess, M. \& Davies, K. E. Syncoilin modulates peripherin filament networks and is necessary for large-calibre motor neurons. J. Cell Sci., 123(Pt. 15):2543-52, 2010.

Cohen, S.; Zhai, B.; Gygi, S. P. \& Goldberg, A. L. Ubiquitylation by Trim32 causes coupled loss of desmin, Z-bands, and thin filaments in muscle atrophy. J. Cell Biol., 198(4):575-89, 2012.

Craig, R. \& Padrón, R. Molecular Structure of the Sarcomere. In: Engel, A. C. \& Franzini-Armstrong, C. (Eds.). Myology. New York, McGraw-Hill, 2004. pp.129-66.

Craig, R. \& Woodhead, J. L. Structure and function of myosin filaments. Curr. Opin. Struct. Biol., 16(2):204-12, 2006.

Deshmukh, L.; Tyukhtenko, S.; Liu, J.; Fox, J. E.; Qin, J. \& Vinogradova, O. Structural insight into the interaction between platelet integrin alphaIIbbeta3 and cytoskeletal protein skelemin. J. Biol. Chem., 282(44):32349-56, 2007.

Dominguez, R. \& Holmes, K. C. Actin structure and function. Аnпи. Rev. Biophys., 40:169-86, 2011.

Donner, K.; Sandbacka, M.; Lehtokari, V. L.; Wallgren-Pettersson, C. \& Pelin, K. Complete genomic structure of the human nebulin gene and identification of alternatively spliced transcripts. Eur. J. Hum. Genet., 12(9):744-51, 2004.

Enns, D. L.; Raastad, T.; Ugelstad, I. \& Belcastro, A. N. Calpain/calpastatin activities and substrate depletion patterns during hindlimb unweighting and reweighting in skeletal muscle. Eur. J. Appl. Physiol., 100(4):445$55,2007$.

Favre, B.; Schneider, Y.; Lingasamy, P.; Bouameur, J. E.; Begré, N.; Gontier, Y.; Steiner-Champliaud, M. F.; Frias, M. A.; Borradori, L. \& Fontao, L. Plectin interacts with the rod domain of type III intermediate filament proteins desmin and vimentin. Eur. J. Cell Biol., 90(5):390-400, 2011.

Gautel, M. \& Goulding, D. A molecular map of titin/connectin elasticity reveals two different mechanisms acting in series. FEBS Lett., 385(12):11-4, 1996

Goldfarb, L. G. \& Dalakas, M. C. Tragedy in a heartbeat: malfunctioning desmin causes skeletal and cardiac muscle disease. J. Clin. Invest., 119(7):1806-13, 2009.

Gordon, A. M., Homsher, E. \& Regnier, M. Regulation of contraction in striated muscle. Physiol. Rev., 80(2):853-924, 2000.

Green, K. J.; Böhringer, M.; Gocken, T. \& Jones, J. C. Intermediate filament associated proteins. Adv. Protein Chem., 70:143-202, 2005.

Grosberg, A.; Kuo, P. L.; Guo, C. L.; Geisse, N. A.; Bray, M. A.; Adams, W. J.; Sheehy, S. P. \& Parker, K. K. Self-organization of muscle cell structure and function. PLoS Comput. Biol., 7(2):e1001088, 2011.

Herrmann, H.; Strelkov, S. V.; Burkhard, P. \& Aebi, U. Intermediate filaments: primary determinants of cell architecture and plasticity. $J$. Clin. Invest., 119(7):1772-83, 2009.
Hijikata, T.; Nakamura, A.; Isokawa, K.; Imamura, M.; Yuasa, K.; Ishikawa, R.; Kohama, K.; Takeda, S. \& Yorifuji, H. Plectin 1 links intermediate filaments to costameric sarcolemma through betasynemin, alpha-dystrobrevin and actin. J. Cell Sci., 121(Pt. 12):206274, 2008.

Hnia, K.; Tronchère, H.; Tomczak, K. K.; Amoasii, L.; Schultz, P.; Beggs, A. H.; Payrastre, B.; Mandel, J. L. \& Laporte, J. Myotubularin controls desmin intermediate filament architecture and mitochondrial dynamics in human and mouse skeletal muscle. J. Clin. Invest., 121(1):70-85, 2011.

Hopkins, P. M. Skeletal muscle physiology. Contin. Educ. Anaesth. Crit. Care Pain, 6(1):1-6, 2006.

Hughes, D. C.; Marcotte, G. R.; Marshall, A. G.; West, D. W. D.; Baehr, L. M.; Wallace, M. A.; Saleh, P. M.; Bodine, S. C. \& Baar, K. Agerelated differences in dystrophin: Impact on force transfer proteins, membrane integrity, and neuromuscular junction stability. J. Gerontol. A Biol. Sci. Med. Sci., 7285):640-8, 2016.

Hughes, D. C.; Wallace, M. A. \& Baar, K. Effects of aging, exercise, and disease on force transfer in skeletal muscle. Am. J. Physiol. Endocrinol. Metab., 309(1):E1-E10, 2015.

Kollár, V.; Szatmári, D.; Grama, L. \& Kellermayer, M. S. Z. Dynamic strength of titin's z-disk end. J. Biomed. Biotechnol., 2010:838530, 2010.

Labeit, S.; Ottenheijm, C. A. \& Granzier, H. Nebulin, a major player in muscle health and disease. FASEB J., 25(3):822-9, 2011.

Lin, B. L.; Song, T. \& Sadayappan, S. Myofilaments: Movers and rulers of the sarcomere. Compr. Physiol., 7(2):675-92, 2017.

Lovering, R. M.; O'Neill, A.; Muriel, J. M.; Prosser, B. L.; Strong, J. \& Bloch, R. J. Physiology, structure, and susceptibility to injury of skeletal muscle in mice lacking keratin 19-based and desmin-based intermediate filaments. Am. J. Physiol. Cell Physiol., 300(4):C80313, 2011.

Marzuca-Nassr, G. N.; Droguett-Cervela, R. A.; Córdova-Sáez, M. P.; Ibarra-Fuentealba, I. A.; Donoso Torres, W. K.; López-Suárez, A. L.; Pacheco, A.; Maulén Arroyo, J.; Márquez, J. L. \& Mancilla-Solorza, E. Acute electrical stimulation modifies cross-sectional area and desmin protein in the skeletal muscle of old rats submitted to hindlimb suspension. Indian J. Physiol. Pharmacol., 61(3):219-31, 2017 a.

Marzuca-Nassr, G. N.; Murata, G. M.; Martins, A. R.; Vitzel, K. F.; Crisma, A. R.; Torres, R. P.; Mancini-Filho, J.; Kang, J. X. \& Curi, R. Balanced diet-fed Fat-1 transgenic mice exhibit lower hindlimb suspension-induced soleus muscle atrophy. Nutrients, 9(10):E1100, 2017b.

Marzuca-Nassr, G. N.; Vitzel, K. F.; De Sousa, L. G.; Murata, G. M.; Crisma, A. R.; Rodrigues Junior, C. F.; Abreu, P.; Torres, R. P.; Mancini-Filho, J.; Hirabara, S. M.; Newsholme, P. \& Curi, R. Effects of high EPA and high DHA fish oils on changes in signaling associated with protein metabolism induced by hindlimb suspension in rats. Physiol. Rep., 4(18):e12958, 2016.

McElhinny, A. S.; Schwach, C.; Valichnac, M.; Mount-Patrick, S. \& Gregorio, C. C. Nebulin regulates the assembly and lengths of the thin filaments in striated muscle. J. Cell Biol., 170(6):947-57, 2005.

Meyer, G. A. \& Lieber, R. L. Skeletal muscle fibrosis develops in response to desmin deletion. Am. J. Physiol. Cell Physiol., 302(11):C1609-20, 2012.

Milner, D. J.; Mavroidis, M.; Weisleder, N. \& Capetanaki, Y. Desmin cytoskeleton linked to muscle mitochondrial distribution and respiratory function. J. Cell Biol., 150(6):1283-98, 2000.

Moore, J. R.; Campbell, S. G. \& Lehman, W. Structural determinants of muscle thin filament cooperativity. Arch. Biochem. Biophys., 594:817, 2016.

Niederländer, N.; Raynaud, F.; Astier, C. \& Chaussepied, P. Regulation of the actin-myosin interaction by titin. Eur. J. Biochem., 271(22):4572-81, 2004

Ogneva, I. V. Transversal stiffness of fibers and desmin content in leg muscles of rats under gravitational unloading of various durations. $J$. Appl. Physiol. (1985), 109(6):1702-9, 2010. 
Ottenheijm, C. A. C. \& Granzier, H. New insights into the structural roles of nebulin in skeletal muscle. J. Biomed. Biotechnol., 2010:968139, 2010.

Pappas, C. T.; Krieg, P. A. \& Gregorio, C. C. Nebulin regulates actin filament lengths by a stabilization mechanism. J. Cell Biol., 189(5):859-70, 2010.

Rui, Y.; Bai, J. \& Perrimon, N. Sarcomere formation occurs by the assembly of multiple latent protein complexes. PLoS Genet., 6(11):e1001208, 2010.

Russ, D. W. \& Grandy, J. S. Increased desmin expression in hindlimb muscles of aging rats. J. Cachexia Sarcopenia Muscle, 2(3):175-80, 2011.

Sanger, J. W.; Wang, J.; Fan, Y.; White, J. \& Sanger, J. M. Assembly and dynamics of myofibrils. J. Biomed. Biotechnol., 2010:858606, 2010.

Seto, J. T.; Lek, M.; Quinlan, K. G.; Houweling, P. J.; Zheng, X. F.; Garton, F.; MacArthur, D. G.; Raftery, J. M.; Garvey, S. M.; Hauser, M. A.; Yang, N.; Head, S. I. \& North, K. N. Deficiency of a-actinin3 is associated with increased susceptibility to contraction-induced damage and skeletal muscle remodeling. Hum. Mol. Genet., 20(15):2914-27, 2011.

Shah, S. B.; Love, J. M.; O'Neill, A.; Lovering, R. M. \& Bloch, R. J. Influences of desmin and keratin 19 on passive biomechanical properties of mouse skeletal muscle. J. Biomed. Biotechnol., 2012:704061, 2012.

Shiroguchi, K.; Chin, H. F.; Hannemann, D. E.; Muneyuki, E.; De La Cruz, E. M. \& Kinosita, K. Jr. Direct observation of the myosin Va recovery stroke that contributes to unidirectional stepping along actin. PLoS Biol., 9(4):e1001031, 2011.

Smythe, G. M.; Davies, M. J.; Paulin, D. \& Grounds, M. D. Absence of desmin slightly prolongs myoblast proliferation and delays fusion in vivo in regenerating grafts of skeletal muscle. Cell Tissue Res., 304(2):287-94, 2001.

Sparrow, J. C. \& Schöck, F. The initial steps of myofibril assembly: integrins pave the way. Nat. Rev. Mol. Cell Biol., 10(4):293-8, 2009.

Steinmetz, M. O.; Goldie, K. N. \& Aebi, U. A correlative analysis of actin filament assembly, structure, and dynamics. J. Cell Biol., 138(3):559-74, 1997.

Tskhovrebova, L. \& Trinick, J. Roles of titin in the structure and elasticity of the sarcomere. J. Biomed. Biotechnol., 2010:612482, 2010.

Winter, L. \& Wiche, G. The many faces of plectin and plectinopathies: pathology and mechanisms. Acta Neuropathol., 125(1):77-93, 2013.

Xu, P. T.; Li, Q.; Sheng, J. J.; Chang, H.; Song, Z. \& Yu, Z. B. Passive stretch reduces calpain activity through nitric oxide pathway in unloaded soleus muscles. Mol. Cell Biochem., 367(1-2):113-24, 2012.

Yanagida, T. \& Oosawa, F. Effect of myosin on conformational changes of F-actin in thin filament in vivo induced by calcium ions. Eur. $J$. Biochem., 56(2):547-56, 1975.

Yu, J. G.; Fürst, D. O. \& Thornell, L. E. The mode of myofibril remodelling in human skeletal muscle affected by DOMS induced by eccentric contractions. Histochem. Cell Biol., 119(5):383-93, 2003.

\author{
Corresponding author: \\ Gabriel Nasri Marzuca-Nassr \\ Faculty of Medicine \\ Universidad de La Frontera \\ Claro Solar 115, Oficina 300, Edificio SA \\ Temuco \\ CHILE
}

E-mail: gabriel.marzuca@ufrontera.cl

Received: 28-06-2017

Accepted: 04-02-2018 